Zamili, M. (2021), "The education process viewed from the standard-based education paradigm in public schools: a case from Central Java, Indonesia", Management and entrepreneurship: trends of development, 1(15), pp. 127-139. Available at: https://doi.org/10.26661/2522-1566/2021-1/15-09

PUBLIC ADMINISTRATION

\section{RECEIVED:}

25 November 2020

ACCEPTED:

25 December 2020

RELEASED:

20 March 2021
UDC $351: 377.1$

DOI 10.26661/2522-1566/2021-1/15-09

\title{
THE EDUCATION PROCESS VIEWED FROM THE STANDARD-BASED EDUCATION PARADIGM IN PUBLIC SCHOOLS: A CASE FROM CENTRAL JAVA, INDONESIA
}

\author{
Moh. Zamili \\ Universitas Ibrahimy \\ East Java, Indonesia \\ ORCID: 0000-0002-6987-8220
}

Authoremail:fine.zam@gmail.com

\begin{abstract}
This study aims to analyse Indonesia's education process using a standard-based education paradigm in the process aspect. The study focused on public high school students on four educational standards released by the Central Java Provincial Education Quality Assurance Agency. Methodology: Case studies were selected based on data from national education standards. Data analysis processed using ATLAS.ti version 8 . The research findings: the results showed the absence of regulations regarding improving teacher qualifications had worsened the standard achievement. Excessive implementation of educational concepts and ignorance of collaborative assessment of spiritual aspects obscures religious tolerance as a hallmark of Indonesian education.
\end{abstract}

Keywords: education process, standard-based education paradigm, central java province.

JEL Classification: I2, I21, I28.

\section{INTRODUCTION}

Today, Indonesia's education process emphasises the transformation of experience into knowledge rather than the transfer of knowledge. This can be seen from the practice of the 2013 revised 2019 curriculum, which emphasises a scientific approach; real-life learning, democratic procedures, and scientific processes, which are Dewey's concepts (Dewey, 2004). Discovery learning and collaborative learning strategies are offered to produce satisfying results to replace a school-based curriculum that was implemented from 2006 to 2012 (Suprapto, 2016). The education paradigm has also been shifted from teacher-centered learning to student-centered learning (Chang et al., 2013). Changes in curriculum and education paradigm did not show significant results in PISA, both in 2012 (64 out of 65 countries), 2015 (fourth from bottom), until the latest report 2018 ranked 72 out of 77 countries (PISA, 2015, 2018, 2012).

The standardised education expectations began since the issuance of Government Regulation of the Republic of Indonesia Number 19 of 2005 concerning National Education Standards which contained the quality of inputs, processes, and outputs. Then in 2013 it was revised on aspects of the content standards (process) and graduate competency standards (output). Drastic changes in content standards and assessment standards by including 21 st-century skills formulations, authentic 
assessments, and higher-order thinking skills assessments that occurred between 2017 and 2019 . The education process is examined in terms of content, process, teacher, and assessment standards. The teacher's role is an input and a comparison factor to the standard process in the paradigm of standards-based education. As definitively standard-based education paradigm is a minimum criterion of the education system in the entire jurisdiction of the Unitary Republic of Indonesia. This is interesting because from the results of a comparative analysis between East Java, Central Java, and West Java, the element of asymmetric teachers with educational process achievements. The most obvious contradiction is seen in the province of Central Java as a locus of research because this province is the first pilot of 34 provinces in Indonesia regarding anti-corruption education and is the first province to stipulate Governor Regulation No. 10 of 2019 concerning the Implementation of Anti-Corruption Education. Not only that, but Central Java also achieved a portrait of the SDGs in mid-2018 (Agency, 2018).

The results of several studies indicate that the qualifications and competence of teachers largely determine the quality of learning (Black and Wiliam, 2006), the quality of assessment management to the quality of education (Hill et al., 2012). This phenomenon is contrary to the reality that occurred in Central Java. Apart from the above problems, the facts show that the implementation of the scientific approach to the 2013 curriculum in Indonesia is in the medium category or not at the analysis stage (Suyanto, 2018). The lack of use of the latest learning models is not appropriate between the stages of the scientific approach and pedagogical competence (Zaim, 2017). Besides, teachers are still confused about applying the scientific approach and linking it with the assessment of attitude, spiritual, and skill aspects.

\section{LITERATURE REVIEW}

The standards-based education paradigm established by the National Education Standards Agency is used as a theoretical basis for studying the educational process. This paradigm has a philosophical foundation on the values of the Pancasila, which accommodates the diversity of tribes, religions, races, and between groups (Kemendikbud, 2012). The theoretical foundation of the Indonesian education process is based on the UNESCO concept of learning to be, learning to do, learning to live together (Faure et al., 1972) and the Bruner theoretical framework (Bruner, 1977; Fusarelli and Johnson, 2004) which was translated in Minister of Education and Culture Regulation of the Republic of Indonesia Number 22 of 2016 concerning Basic and Secondary Education Process Standards, 2016. For content standards, it is based on Anderson and Krathwohl's revision of cognitive processes (Anderson et al., 2001; Krathwohl, 2002). The cognitive process of Anderson and Krathwohl above is translated into two regulations: (a) Regulation of the Minister of Education and Culture of the Republic of Indonesia Number 21 of 2016 concerning Standard Content of Elementary and Secondary Education, (b) Regulation of the Minister of Education and Culture of the Republic of Indonesia Number 103 of 2014 concerning Learning on Basic Education and Secondary Education. Through these regulations, the learning process is named a scientific approach.

Organising learning experiences summarised in a scientific approach consists of five steps: observing, questioning, experimenting, associating, and communicating. The process is embedded with authentic assessments (Gulikers et al., 2004; Kemendikbud, 2013) and applying higher-order thinking skills to measure aspects of knowledge, attitudes, and skills (Brookhart, 2010; Kemendikbud, 2013). Thus, the learning process through assessment, since 2013, followed the 2013 curriculum format (Pratiwi, 2019). From a school-based curriculum to the 2013 curriculum, national education standards are adjusted between the eight standards on behalf of curriculum development. Eight national education standards are the minimum criteria for the education system in the entire jurisdiction of the Unitary Republic of Indonesia is shown in the following Figure 1. 
Zamili, M. (2021), "The education process viewed from the standard-based education paradigm in public schools: a case from Central Java, Indonesia", Management and entrepreneurship: trends of development, 1(15), pp. 127-139. Available at: https://doi.org/10.26661/2522-1566/2021-1/15-09

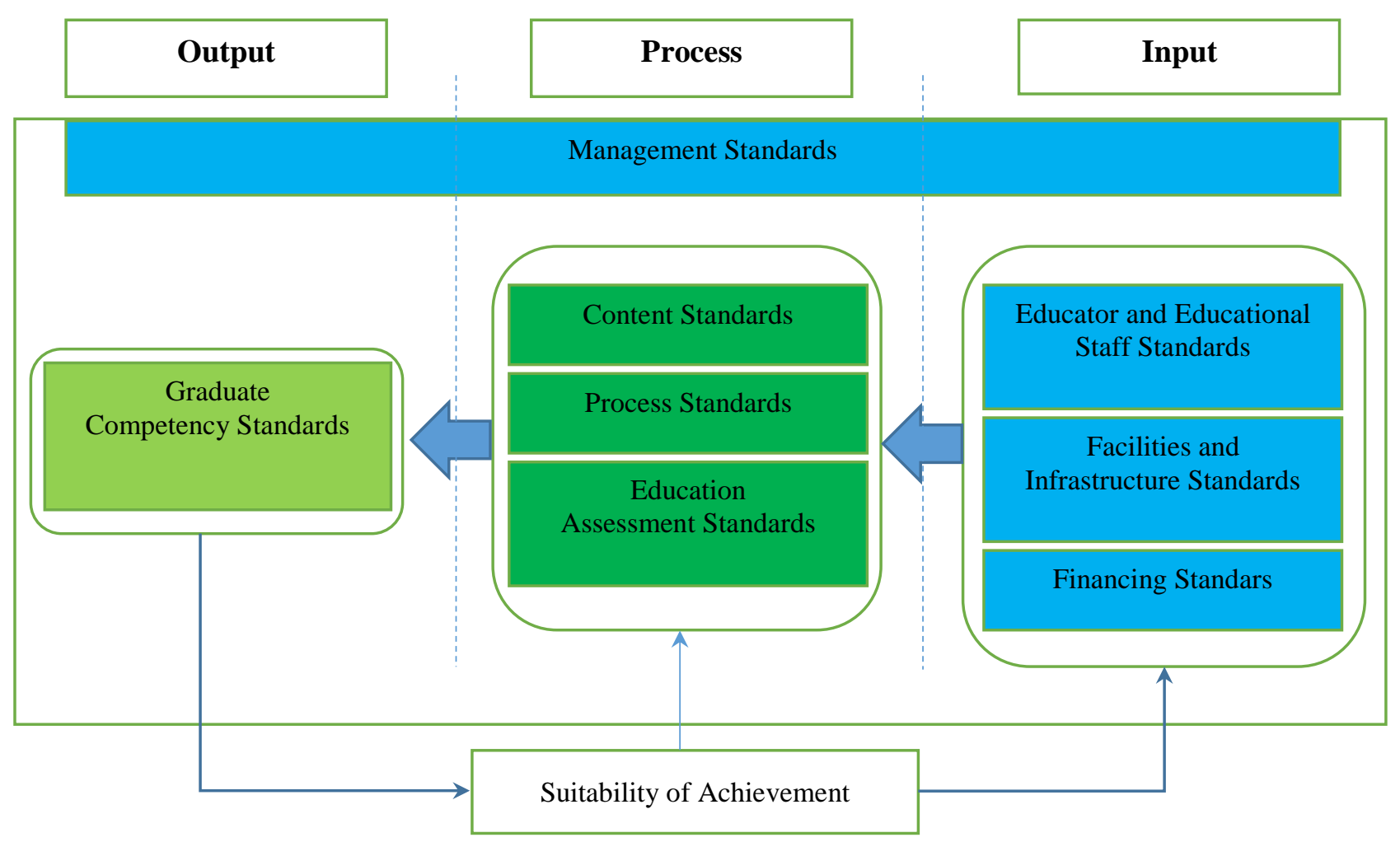

Figure 1. Standard Based Education Paradigm

Source: National Education Standards Agency, 2019.

Standards-based education aims to manage students' knowledge, attitudes, and skills competencies. In this study, the three competencies are processed based on four main categories, namely: (a) content standards, (b) process standards, (c) education assessment standards, (d) educator and education staff standards. The content standard contains the formulation of graduate competencies, curriculum development procedures, and curriculum implementation. Implementing the scientific approach to the 2013 curriculum in Indonesia is in the medium category or not at the analysis stage (Suyanto, 2018). The lack of use of the latest learning models (Gunawan, 2017), is not appropriate between the steps of the scientific approach and pedagogical competence (Zaim, 2017). Besides, teachers are still confused about applying the scientific approach and linking it with assessing attitude, spiritual, and skill aspects. Some of the studies above contradict the high teacher qualifications in five districts/cities, which were $96.55 \%$ in Pekalongan, Surakarta $98.32 \%$, Tegal 97.78\%, Semarang 98.44\%, Salatiga 98.19\% with an average: 97.9 in 2019 (Disdikbud-Jateng, 2019).

Process standards contain planning, process, and assessment of learning. Educational assessment standards include (a) aspects of assessment and competence, (c) objectivity and accountability of assessment techniques, (d) follow-up assessment, (e) appropriateness of instruments and competency aspects, (f) assessment procedures. The above elements are managed by teachers, education units, and the government. Recent developments in the national mass media show that learning plans' preparation is simplified into one sheet. This saves on administrative procedures efficiently and effectively is done so that the teacher has plenty of time to prepare and evaluate the learning process. Thus, what is written in the learning implementation plan will be acted out in the learning process. Meanwhile, there are not many changes regarding the standards of educators and education personnel in Indonesia, especially regarding the qualification criteria. Since 
law number 20 of 2003 regarding the national education system was translated into Republic of Indonesia Government Regulation Number 32 of 2013 concerning Amendment to Government Regulation Number 19 of 2005 concerning National Education Standards, qualifications have never been touched.

\section{PAPER OBJECTIVE}

In general, this study aims to analyse the educational process used a standards-based education paradigm following question:

(1) how is the condition of the education process in Indonesia viewed from the achievement of the process's national standard aspects?

(2) what are the inhibiting factors on the achievement of standard processes?

\section{METHODOLOGY}

The selection of five districts/cities is due to several reasons: (1) the achievement of national education standards that almost touches the minimum standard, (2) has several suitable reference schools for the surrounding schools, (3) dynamic teacher qualifications. The selection of these sites is supported by secondary data on high school level quality report cards throughout Java released by the Educational Quality Assurance Institute. Based on the above reasons the researchers grouped by category from five districts/cities consisting of 100 schools in Pekalongan, 322 schools in Surakarta, 158 Schools in Tegal, 584 schools in Semarang, and 113 schools in Salatiga. The data is analysed thematically and carried out with focus groups that involve the Head of Primary and Secondary Schools and the Head of General Affairs (Caillaud and Flick, 2017). An examination of the Education Quality Assurance Agency data occurred between July 2019 and January 2020 was compared with data released by the planning department and statistics team at the Office of Education and Culture of Central Java Province. Selected case study strategies to track contemporary and real events (Yin, 2018). The complexity of the phenomenon is revealed through the Miles-Huberman model data analysis procedure coupled with the Creswell data validity, triangulation model, and the use of ATLAS.ti version 8 in processing data (Creswell and Creswell, 2018; Miles et al., 2014).

\section{RESULT AND DISCUSSION}

\section{Result}

\section{Schooling, training is not enough}

17 years is enough time to make a regulation that teachers must have a bachelor's degree. This phenomenon has occurred since the issuance of Law number 20 of 2003 concerning the national education system. Even the government regulations on national education standards that changed from 2005 to 2013 also did not touch the issue of increasing teacher qualification standards. Improving qualifications is not enough to be done through training which tends to be held three days to a week. Improving qualifications is not just about achieving an academic degree but is questioning a mindset, a culture set, and improving the quality of education. The question, is the government ready to face a surge in teacher qualifications that automatically increase salaries? Given the number of teachers consisting of two ministries; teachers in the ministry of education totalled $2,720,778$, and the ministry of religion totalled 767,952 from primary schools, special schools to senior high schools in 2018/2019 school year. This number does not include private school/madrasah teachers and special religious schools. Noting the facts above, I do a minimum recapitulation of S1/D4 qualification as one of the standard educators as listed in the following chart: 
Zamili, M. (2021), "The education process viewed from the standard-based education paradigm in public schools: a case from Central Java, Indonesia", Management and entrepreneurship: trends of development, 1(15), pp. 127-139. Available at: https://doi.org/10.26661/2522-1566/2021-1/15-09

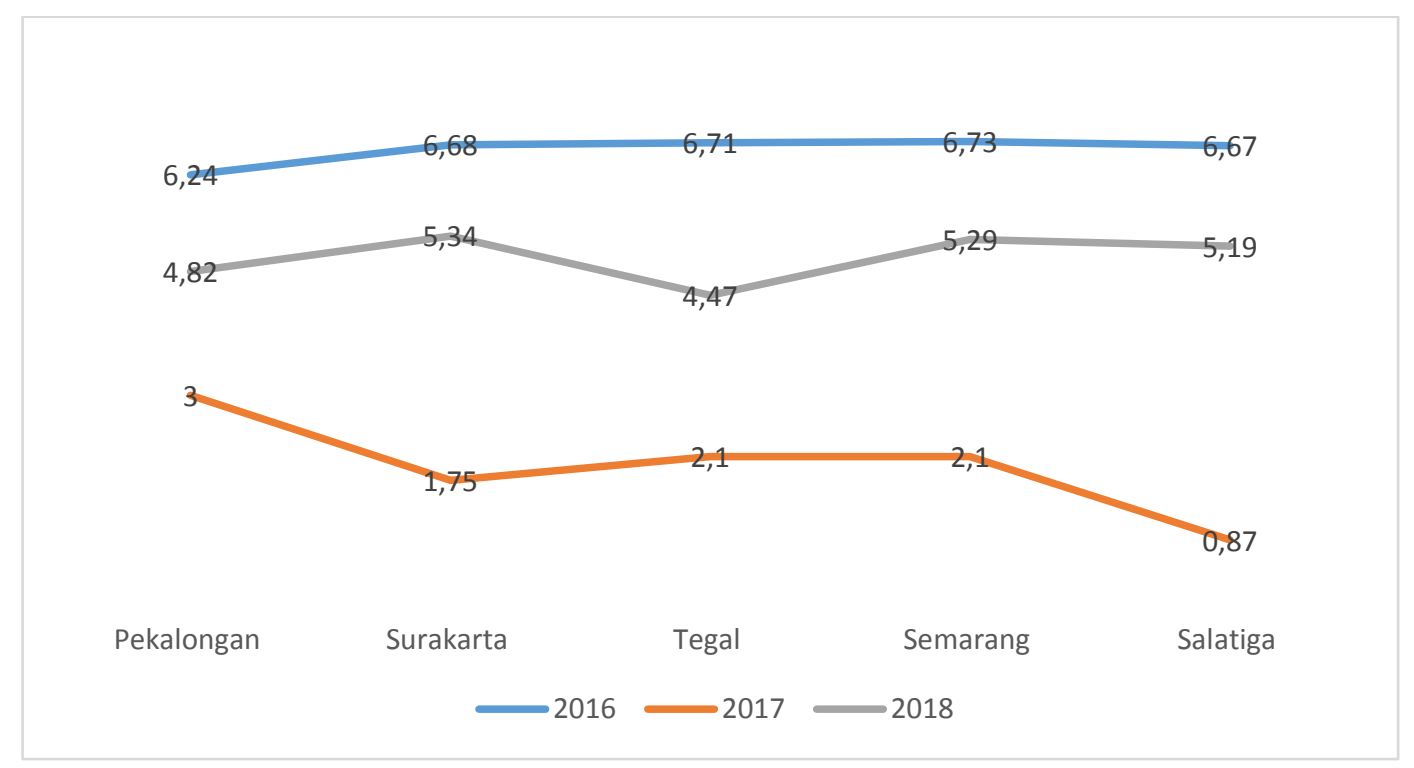

Graph 1. Development of Teacher Qualifications

Source: Central Java Province Educational Quality Assurance Institute, 2019.

Graph 1 displays teacher qualifications development from 2016 to 2018, which never reached the minimum standard at number seven. Besides, the government has facilitated the matter of competency development in the arrow's direction with a qualification called the teacher competency test. Teacher professional development through teacher competency tests is not reciprocal because it is limited to testing pedagogical and professional aspects, as shown in Figure 2.

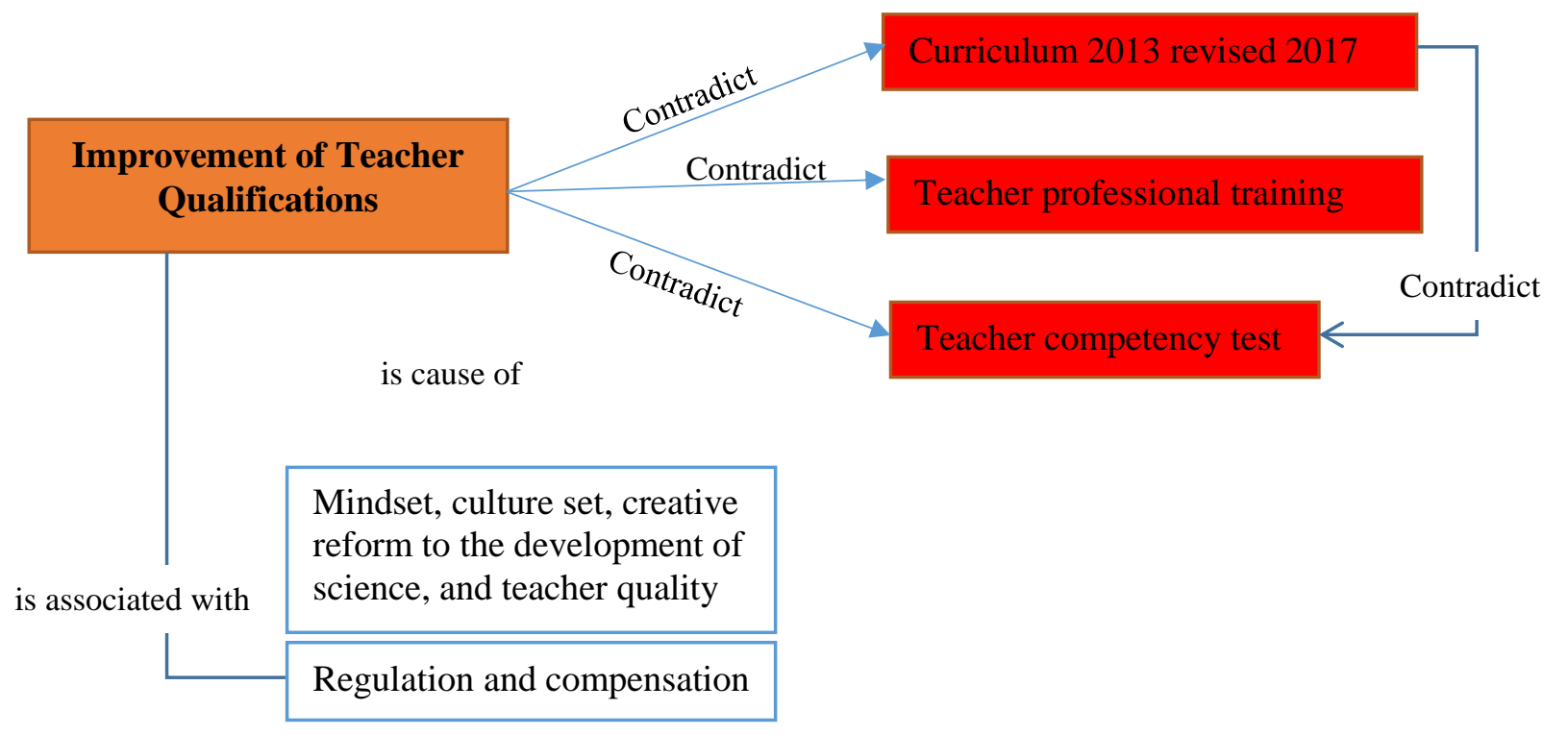

Figure 2. Teacher Competency Standard Conditions

Source: Own compilation. 


\section{Menu variants in the education process}

In line with the implementation of the scientific approach, in 2017 until now the government launched a learning package in the form of strengthening character education, school literacy movement, communication-based learning, collaboration, critical thinking, creativity (called 4C), and strengthening higher-order thinking skills. The story of the presence of strengthening character education stems from the fact that in the next 25 years, Indonesia will reach a century, but beyond that, for the last ten years, the practice of corruption has spread from ministers to bureaucrats in the countryside. To face the challenges of a century while improving the nation's generation, strengthening character education is seen as urgent in the face of demographic bonus in 2045 and translating the issue in Presidential Regulation No. 87 of 2017 concerning Strengthening Character Education, 2017.

The second menu is led to school literacy movements. It is a contrasting phenomenon considering that the number of libraries in Indonesia is the second-largest globally in mid-2019. The number of libraries scattered in various regions is 164,610. The largest number of library infrastructure after India, amounting to 323,605 libraries. The world's number two library infrastructure is under India and above Russia, with 113,440 libraries. China ranks fourth with 105,831 libraries. In short, the number of libraries is inversely proportional to reading habits and interests. The last package of the learning menu is the $4 \mathrm{C}$ learning concept is a translation of 21 stcentury skills theory. The conceptual characteristics of the concept are similar to the scientific approach and in line with Krathwohl's taxonomy. In the name of renewal of the latest educational developments, the $4 \mathrm{C}$ concept is part of the 2019 curriculum revision, which tends to be redundant because of its similarity.

\section{Formulation of competencies and learning strategies}

The correlation between the formulation of competencies and the use of learning strategies tends to be ignored. Teachers often focus on using strategies, whereas learning is a change in mindset and behaviour derived from why and how students learn. As noted by the Educational Quality Assurance Agency, this phenomenon regarding the achievement of the indicator "adjusts the level of competence of students [competency formulation]" with an average of 3.8. While the indicator "the learning process is implemented appropriately [use of learning strategies]" is at an average of 6.7. Both achievement disparities are due to a contradiction between the competencies that students must master (spiritual aspects and spiritual attitude) and teacher competencies (social and personality competency aspects), as shown in figure 2, never tested through teacher competency test instruments. 
Zamili, M. (2021), "The education process viewed from the standard-based education paradigm in public schools: a case from Central Java, Indonesia", Management and entrepreneurship: trends of development, 1(15), pp. 127-139. Available at: https://doi.org/10.26661/2522-1566/2021-1/15-09

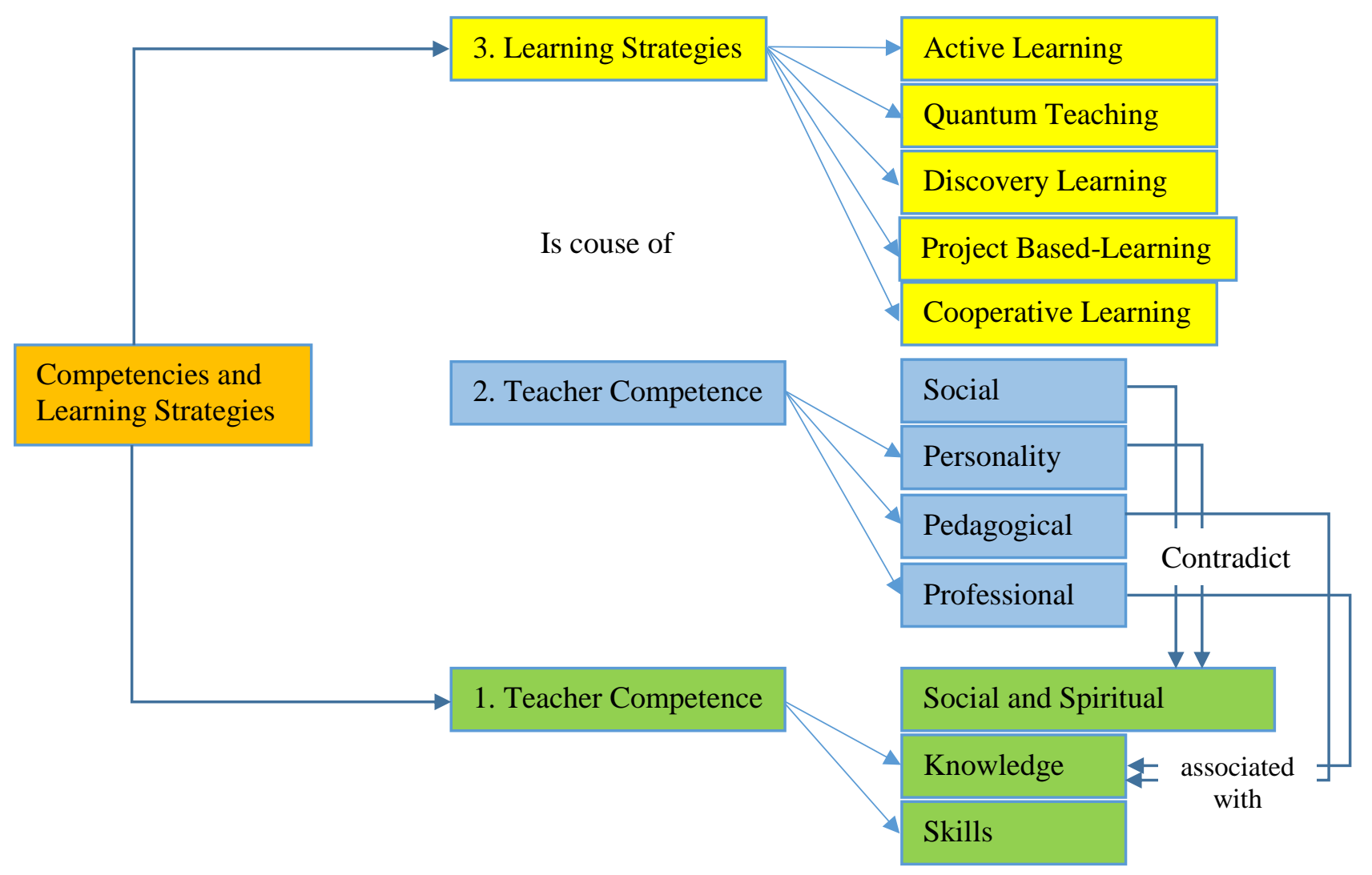

Figure 3. Competencies and Learning Strategies

\section{Source: Own compilation.}

The competency formulation above is processed using various learning strategies oriented to achieving learning effectiveness, such as implementing active learning and cooperative learning. The two strategies are said to be current because the 2013 curriculum changes emphasise the two strategy variants. In the past five years, the discovery/inquiry learning approach has been touted as an approach that fits the characteristics of 21 st-century learning.

\section{Educational Assessment Process}

The fundamental difference from the latest education assessments that have been in effect since 2017/2018 until the 2018/2019 school year is about the assessment approach. The dimensions of the assessment approach are translated using higher-order thinking skills and authentic assessment designs. The complexity of assessment requires teachers to explore various approaches to learning for assessment and assessment as learning. Unfortunately, the research findings show a contrast in the aspect of evaluating spiritual attitudes.

The assessment process is submitted to the guidance counselling teacher and the homeroom teacher without involving students' parents as users of the assessment results. Even though the aspects of spirituality cannot be separated from Indonesia's characteristics, which are religious and upholds religious tolerance. Education starts with the family, especially religious education, all starting from the family, but unfortunately, spiritual assessment is still considered an academic assessment. Spirituality is not a matter of achieving numbers on report cards. But the increase in obedience, tolerance, integrity, and the like begins with the family. 


\section{Discussion}

Until now, the aspect of increasing teacher competency has only been focused on training programs. There is nothing wrong with the variety of training to improve competence (Arnott, 2000; Looney, 2011; Rothstein, 2010; Vagi, Pivovarova, and Barnard, 2019), but for me, the effect is very small in the aspects of innovation and improvisation of learning. Best practice from several countries has shown that competence, teaching experience, and improved qualifications go hand in hand with improved learning processes (Mctavish, 2003; Tolofari, 2005), progress in learning outcomes, and quality of education (Croninger et al., 2007; Guo et al., 2012; Qin and Bowen, 2019). Training does not change the teacher's mindset so that teaching is like a machine with strategies obtained throughout the training course. In addition to training, the professional teacher program that has been in effect since 2012 as an effort by the government to develop teacher professionalism has not been significant in improving education quality. Several problems were encountered, such as the urge to revitalise the Educational Personnel Educational Institution's quality assurance as to the program implementer and the loosening of teacher candidate participants' selection.

In the aspect of the process, the first round of problems encountered was inequality in the management of spiritual attitudes and social attitudes curricular managed by religious teachers and civic education teachers. On the other hand, all subject teachers, homeroom teachers, and counseling guidance teachers manage these two competencies through a journal summary that contains a brief description of the progress or setbacks of student attitudes. Indeed, a collaboration of excessive, redundant, and formalistic student competency management. Considering that there are already student teachers and school committees in the school structure that are rarely involved, especially the lack of involvement of parents in competency monitoring. Even recent research shows that teachers still assume the evaluation of the spiritual aspects as the academic domain and not the appreciation and change of good behavior in daily life (Zamili, Suwitri, Dwimawanti and Kismartini, 2020). Meanwhile, social competencies and personalities that have never been tested in teacher competency test instruments are increasingly asymmetrical with the achievement of socialspiritual competencies that students must master, even though in the context of wider social relations, the links between the two cannot be separated (French et al., 2013).

The second half of the revision of the learning process began in 2017 with four learning programs, namely: (a) strengthening character education, (b) school literacy movements, (c) 4C, and (d) Strengthening higher-order thinking skills. Until now, uncertainty about the practice of strengthening character education is because there has not been a partnership between character education built by schools and foundations built by families. Collaboration between the two sides is not enough when considering Indonesia's diverse social conditions. On the other hand, good and competitive character-building needs to pay attention to planned multicultural education (Malihah, 2015) given the diversity of cultures, languages, ethnicities, religions, and between groups and the importance of comprehensive intelligence from intellectual to spiritual. Meanwhile, the school literacy movement package is oriented to uplift Indonesian students' literacy, which is hampered by access to virtual-based reading material and the accumulation of urban libraries. The results of studies published under the name "The World's Most Literate Nations" ranks Indonesia 60th, only one level above Botswana (Miller and McKenna, 2016). Some research results also explain the lack of school commitment to form a school literacy team (Pantiwati, Permana, Kusniarti and Miharja, 2020) and the literacy program's low intensity for schools that have a literacy team.

The next package that is warm in the education process is $4 \mathrm{C}$ learning. The $4 \mathrm{C}$ concept is the ministry of education's interpretation of 21st-century skills coupled with the practice of higher-order thinking skills breathing the taxonomy of Krathwohl (Krathwohl, 2002). Combining the learning process menu is a challenge and a new problem in the education system. The four menus must be available and complete in the lesson plan that began since implementing the 2013 revised 2017 
Zamili, M. (2021), "The education process viewed from the standard-based education paradigm in public schools: a case from Central Java, Indonesia", Management and entrepreneurship: trends of development, 1(15), pp. 127-139. Available at: https://doi.org/10.26661/2522-1566/2021-1/15-09

curriculum. Adaptation is made again by creating a new label and the 2013 revised 2019 curriculum. It is only a matter of how to list KI 1 and KI 2 (called, first core competencies and second) in the lesson plan. The repetition terminology is changed to an assessment, and there is no need to include a column of learning methods in the lesson plan. Indeed, the revision is insignificant compared to the Republic of Indonesia's unitary unity, which amounts to thousands of islands with two ministries managing education through different paradigms. An ambitious variety of menus to raise the achievement of four standards with an average of 5.4 from the 7.0 target released by the Central Java Provincial Education Quality Assurance Institute. Central Java has the potential to develop better education processes, given the initial data pointing towards the development of standardised education quality. The pattern of collaboration between actors, namely the Office of Education and Culture of Central Java Province, the Institute for Quality Assurance of Education, and the education unit in the management of education is very urgent to face the challenges of the golden generation 2045 .

\section{CONCLUSION}

The standardised education process requires an increase in teachers' qualifications who have been untouched for 17 years. As a front guard in developing students' competencies, teachers cannot be exchanged with technological developments. On the other hand, the achievement of students' social and spiritual competencies is not compatible with social and personality competencies that educational quality assurance agencies have never measured. Whereas social attitude education and spiritual attitude cannot be replaced. That is, teachers must still practice examples of good behavior in daily life because students cannot be likened to search engines like Google or YouTube. Throughout the study, the learning process of educational assessment has not yet become a unified whole. Changing regulations show weak government commitment to the advancement of education. The four years of government are marked by curriculum revisions that have implications for the learning process. Unfortunately, the revisions made were not significant with the needs of the education unit and global needs, as PISA noted. I admit that PISA does not measure the assessment of social-spiritual attitudes, but in the Indonesian context, the neglect of measuring social-spiritual attitudes has implications for the blurring of the characteristics of religious tolerance.

\section{REFERENCES}

Anderson, L. W. (2008), Classroom Assessment: Enhancing the Quality of Teacher Decision Making, London: Taylor and Francis e-Library.

Anderson, L. W., Krathwohl, D. R., Airasian, P. W., Cruikshank, K. A., Mayer, R. E., Pintrich, P. R., ... Wittrock, M. C. (2001), A Taxonomy for Learning, Teaching, and Assessing: A Revision of Bloom's Taxonomy of Educational Objectives, Abridged Edition, New York: Longmans.

Arends, R. I. (2012), Learning to Teach (9th ed.); M. Ryan, B. Mejia, and A. McNamara, Eds., New York: McGraw-Hill.

Arnott, M. A. (2000), "Restructuring the Governance of Schools: the impact of managerialism on schools in Scotland and England", The Governance of Schooling: comparative studies of devolved management, M. A. Arnott and C. D. Raab (Eds.), pp. 43-63, London: Routledge.

Black, P. and Wiliam, D. (2006), "Assessment for Learning in the Classroom", J. Gardner (Ed.), Assessment and Learning (1st ed.), pp. 9-26, London: Sage.

Bloom, B. S. (1956), Taxonomy Of Educational Objectives, The Classification of Educational Goals: Handbook 1 Cognitive Domain, USA: Longmans. 
Brookhart, S. M. (2010), How to Assess Higher-Order Thinking Skills in your Classroom, Alexandria: ASCD.

Bruner, J. S. (1977), The Process of Education (2nd ed.), London: Harvard University Press.

Caillaud, S. and Flick, U. (2017), "Focus Groups in Triangulation Contexts", A New Era in Focus Group Research: Challenges, Innovation and Practice, R. S. Barbour and D. L. Morgan (Eds.), pp. 155-178, Palgrave Macmillan.

Chang, M. C., Shaeffer, S., Al-Samarrai, S., Ragatz, A. B., de Ree, J. and Stevenson, R. (2013), Teacher Reform in Indonesia: The Role of Politics and Evidence in Policy Making. https://doi.org/10.1596/978-0-8213-9829-6.

Creswell, J. W. and Creswell, J. D. (2018), Research Design: Qualitative, Quantitative, and Mixed Methods Approaches (5th ed.), London: Sage.

Croninger, R. G., Rice, J. K., Rathbun, A. and Nishio, M. (2007), "Teacher qualifications and early learning: Effects of certification, degree, and experience on first-grade student achievement", Economics of Education Review, 26(3), 312-324. Available at: https://doi.org/10.1016/j.econedurev.2005.05.008.

Darling-Hammond, L. (2000), "Teacher Quality and Student Achievement: A Review of State Policy Evidence", Education Policy Analysis Archives, 8(1), pp. 1-44.

Dewey, J. (2004), Democracy and Education: an Introduction to the Philosophy of Education, Delhi: Aakar Books.

Disdikbud-Jateng. (2019), "Kualifikasi Guru SMA Negeri Jawa Tengah", Kualifikasi, (in Indonesian).

Faure, E., Herrera, F., Kaddoura, A.-R., Lopes, H., Petrovsky, A. V., Rahnema, M. and Ward, F. C. (1972), Learning to be: The World of Education Today and Tomorrow, Paris: UNESCO.

Flick, U. (2014), An Introduction to Qualitative Research (5th ed.), Thousand Oaks, CA: Sage.

French, D. C., Eisenberg, N., Sallquist, J., Purwono, U., Lu, T. and Christ, S. (2013), "ParentAdolescent relationships, religiosity, and the social adjustment of Indonesian muslim adolescents", Journal of Family Psychology, 27(3), pp. 421-430. Available at: https://doi.org/10.1037/a0032858.

Fusarelli, L. D. and Johnson, B. (2004), "Educational governance and the new public management", Public Administration and Management, 9(2), pp. 118-127.

Gerring, J. (2016), Case Study Research: Principles and Practices (2nd ed.), Oxford: Oxford University Press.

Gulikers, J. T. M., Bastiaens, T. J. and Kirschner, P. A. (2004) "A Five-Dimensional Framework for Authentic Assessment", Educational Technology Research and Development, 52(3), pp. 6786. Available at: https://doi.org/10.1007/BF02504676.

Gunawan, I. (2017), "Instructional Management in Indonesia: A Case Study", Researchers World: Journal of Arts, Science and Commerce, VIII(1), pp. 99-107. Available at: https://doi.org/10.18843/rwjasc/v8i1/12.

Guo, Y., Connor, C. M. D., Yang, Y., Roehrig, A. D. and Morrison, F. J. (2012), "The effects of teacher qualification, teacher self-efficacy, and classroom practices on fifth graders' literacy outcomes", Elementary School Journal, 113(1), pp. 3-24. Available at: https://doi.org/10.1086/665816.

Hill, H. C., Umland, K., Litke, E. and Kapitula, L. R. (2012), "Teacher Quality and Quality Teaching: Examining the Relationship of a Teacher Assessment to Practice", American Journal of Education, 118(4), pp. 489-519. Available at: https://doi.org/10.1086/666380.

Kemendikbud (2012), Uji Publik: Pengembangan Kurikulum 2013, Jakarta: Kementerian Pendidikan dan Kebudayaan Republik Indonesia, (in Indonesian).

Kemendikbud (2013), Kerangka Dasar dan Struktur Kurikulum 2013, Jakarta: Kementerian Pendidikan dan Kebudayaan Republik Indonesia, (in Indonesian). 
Zamili, M. (2021), "The education process viewed from the standard-based education paradigm in public schools: a case from Central Java, Indonesia", Management and entrepreneurship: trends of development, 1(15), pp. 127-139. Available at: https://doi.org/10.26661/2522-1566/2021-1/15-09

Krathwohl, D. R. (2002), "A Revision of Bloom's Taxonomy: An Overview", Theory Into Practice, 41(4), pp. 212-264. Available at: https://doi.org/10.1207/s15430421tip4104_2.

Lewis, A. and Smith, D. (1993), "Defining Higher Order Thinking", Theory into Practice, 32(3), pp. 131-137. Available at: https://doi.org/10.1080/00405849309543588.

Looney, J. (2011), "Developing High-Quality Teachers: teacher evaluation for improvement", European Journal of Education, 46(4), pp.440-455. Available at: https://doi.org/10.1111/j.1465-3435.2011.01492.x.

Malihah, E. (2015), "An ideal Indonesian in an increasingly competitive world: Personal character and values required to realise a projected 2045 "Golden Indonesia", Citizenship, Social and Economics Education, 14(2), pp.148-156. Available at: https://doi.org/10.1177/2047173415597143.

Malinen, O. P., Väisänen, P. and Savolainen, H. (2012), "Teacher education in Finland: A review of a national effort for preparing teachers for the future", Curriculum Journal, 23(4), pp.567584. Available at: https://doi.org/10.1080/09585176.2012.731011.

Mctavish, D. (2003), "Aspects of Public Sector Management: A Case Study of Further Education, Ten Years from the Passage of the Further and Higher Education Act", Educational Management and Administration, 31(2), pp. 175-187.

Miles, M. B., Huberman, A. M. and Saldaña, J. (2014), Qualitative Data Analysis: A Methods Sourcebook (3rd ed.), Los Angeles: Sage.

Miller, J. W. and McKenna, M. C. (2016), World Literacy: How Countries Rank and Why It Matters, Routledge.

Ministry of National Development Planning, National Development Planning Agency (2018), Roadmap of SDGs Indonesia: A Highlight. Available at: https://www.unicef.org/indonesia/media/1626/file/Roadmap of SDGs.pdf (Accessed 15 November 2020).

Mueller, J. (2005), "The Authentic Assessment Toolbox: Enhancing Student Learning through Online Faculty Development", Journal of Online Learning and Teaching, 1(1), pp. 1-8. Available at: http://jolt.merlot.org/documents/VOL1No1mueller.pdf (Accessed 15 Nivember 2020).

Pantiwati, Y., Permana, F. H., Kusniarti, T. and Miharja, F. J. (2020), "The Characteristics of Literacy Management in School Literacy Movement (SLM) at Junior High School in Malang - Indonesia", Asian Social Science, 16(4), pp. 15-24. Available at: https://doi.org/10.5539/ass.v16n4p15.

Permendikbud (2013), Peraturan Menteri Pendidikan dan Kebudayaan Republik Indonesia Nomor 81a Tahun 2013 Tentang Implementasi Kurikulum, (in Indonesian).

Permendikbud (2013), Peraturan Menteri Pendidikan Pendidikan Dan Kebudayaan Republik Indonesia Nomor 69 Tahun 2013 Tentang Kerangka Dasar dan Struktur Kurikulum Sekolah Menengah Atas/Madrasah Aliyah, (in Indonesian).

OECD (2017), PISA 2015 Results (Volume V): Collaborative Problem Solving, PISA, OECD Publishing, Paris. Available at: http://dx.doi.org/10.1787/9789264285521-en.

OECD (2018), PISA 2018 Result in Focus, PISA, OECD Publishing, Paris. Available at: https://www.oecd.org/pisa/publications/pisa-2018-results.htm (Accessed 15 November 2020).

OECD (2014), PISA 2012 Results in Focus PISA, OECD Publishing, Paris. Available at: https://www.oecd.org/pisa/keyfindings/pisa-2012-results-overview.pdf (Accessed 15 November 2020).

Pratiwi, I. (2019), "PISA Effect on Curriculum In Indonesia", Jurnal Pendidikan Dan Kebudayaan, 4(1), pp.51-71. Available at: https://doi.org/10.24832/jpnk.V4i1.1157, (in Indonesian).

Qin, L. and Bowen, D. H. (2019), "The distributions of teacher qualification: A cross-national study", International Journal of Educational Development, 70, 102084. Available at: https://doi.org/10.1016/j.ijedudev.2019.102084. 
Rice, J. K. (2010), "The Impact of Teacher Experience: Examining the Evidence and Policy Implications", Brief No. 11, National Center for Analysis of Longitudinal Data in Education Research, The Urban Institute. Available at: http://citeseerx.ist.psu.edu/viewdoc/download;jsessionid=5BD2295B6B3411B5E0E85637A3 6861BC? doi=10.1.1.307.2325\&rep=rep1\&type=pdf (Accessed 15 November 2020).

Rothstein, J. (2010), "Teacher Quality in Educational Production: Tracking, Decay, and Student Achievement", Quarterly Journal of Economics, 125(1), pp. 175-214. Available at: https://doi.org/10.1162/qjec.2010.125.1.175.

Stake, R. E. (2006), Multiple Case Study Analysis, The Guilford Press.

Suprapto, N. (2016), "What should educational reform in Indonesia look like? - Learning from the PISA science scores of East-Asian countries and Singapore", Asia-Pacific Forum on Science Learning and Teaching, 17(2), pp. 1-22.

Suyanto, S. (2018), "The Implementation of the Scientific Approach through 5Ms of the Revised Curriculum 2013 in Indonesia", Cakrawala Pendidikan, 37(1), pp. 22-29.

Tirri, K. (2014), "The last 40 years in Finnish teacher education", Journal of Education for Teaching, 40(5), pp. 600-609. Available at: https://doi.org/10.1080/02607476.2014.956545.

Tobias, J., Wales, J. and Syamsulhakim, E. (2014), Toward Better Education: Indonesia's Promising Path, Development Progress Case Study Summary, Overseas Development Institute. Available at: https://www.odi.org/sites/odi.org.uk/files/odi-assets/publicationsopinion-files/9066.pdf (Accessed 15 November 2020).

Tolofari, S. (2005), "New Public Management and Education", Policy Futures in Education, 3(1), pp. 75-89. Available at: https://doi.org/10.2304/pfie.2005.3.1.11.

Vagi, R., Pivovarova, M. and Barnard, W. (2019), "Dynamics of preservice teacher quality", Teaching and Teacher Education, 85, pp. 13-23. Available at: https://doi.org/10.1016/j.tate.2019.06.005.

Wiliam, D. (2009), Assessment for Learning: Why, What and How? London: Institute of Education, University of London.

Yin, R. K. (2018), Case Study Research and Applications: Design and Methods (6th ed.), Thousand Oaks, CA: Sage.

Zaim, M. (2017), "Implementing Scientific Approach to Teach English at Senior High School in Indonesia", Asian Social Science, 13(2). Available at: https://doi.org/10.5539/ass.v13n2p33.

Zamili, M., Suwitri, S., Dwimawanti, I. H. and Kismartini, K. (2020), "Management of Educational Assessment in High School: Transcendental Factors", Management and Entrepreneurship: Trends of Development, 1(11), pp. 81-97. Available at: https://doi.org/10.26661/25221566/2020-1/11-06.

Zuljan, M. V. and Vogrinc, J. (2011), "European dimensions of teacher education : similarities and differences", CEPS Journal, 1(2), pp. 105-113. Available at: https://www.cepsj.si/index.php/cepsj/article/view/431/252 (Accessed 15 November 2020).

\title{
НАВЧАЛЬНИЙ ПРОЦЕС У СВІТЛІ СТАНДАРТНОЇ ОСВІТНЬОЇ ПАРАДИГМИ В ДЕРЖАВНИХ ШКОЛАХ: ПРИКЛАД ЦЕНТРАЛЬНОЇ ЯВИ, ІНДОНЕЗІЯ
}

\author{
Moh. Zamili \\ Universitas Ibrahimy \\ East Java, Indonesia
}

Метою даного дослідження є аналіз освітнього процесу в Індонезії з використанням стандартної парадигми освіти в процесуальному аспекті. Дослідження було зосереджено на учнях державних середніх шкіл за чотирма освітніми стандартами, підготовленим Агентством 3 забезпечення якості освіти провінції Центральна Ява. Методологія 
Zamili, M. (2021), "The education process viewed from the standard-based education paradigm in public schools: a case from Central Java, Indonesia", Management and entrepreneurship: trends of development, 1(15), pp. 127-139. Available at: https://doi.org/10.26661/2522-1566/2021-1/15-09

дослідження: тематичні дослідження були відібрані на основі даних національних освітніх стандартів. Аналіз даних оброблений за допомогою ATLAS.ti версії 8. Результати дослідження показали, що відсутність нормативних документів щодо підвищення кваліфікації вчителів погіршило досягнення показників стандарту. Надмірне використання освітніх концепцій і ігнорування спільної оцінки духовних аспектів ускладнює розуміння релігійної терпимості як відмінної ознаки індонезійської освіти.

Ключові слова: освітній процес, стандартна парадигма освіти, Центральна провінція Ява.

\title{
УЧЕБНЫЙ ПРОЦЕСС В СВЕТЕ СТАНДАРТНОЙ ОБРАЗОВАТЕЛЬНОЙ ПАРАДИГМЫ В ГОСУДАРСТВЕННЫХ ШКОЛАХ: ПРИМЕР ЦЕНТРАЛЬНОЙ ЯВЫ, ИНДОНЕЗИЯ
}

\author{
Moh. Zamili \\ Universitas Ibrahimy \\ East Java, Indonesia
}

Целью данного исследования является анализ образовательного процесса в Индонезии с использованием стандартной парадигмы образования в процессуальном аспекте. Исследование было сосредоточено на учащихся государственных средних школ по четырем образовательным стандартам, подготовленным Агентством по обеспечению качества образования провинции Центральная Ява. Методология исследования: тематические исследования были отобраны на основе данных национальных образовательных стандартов. Анализ данных обработан с помощью ATLAS.ti версии 8. Результаты исследования показали, что отсутствие нормативных документов по повышению квалификации учителей ухудшило достижение показателей стандарта. Чрезмерное внедрение образовательных концепций и игнорирование совместной оценки духовных аспектов затрудняет понимание религиозной терпимости как отличительного признака индонезийского образования.

Ключевые слова: образовательный процесс, стандартная парадигма образования, Центральная провинция Ява. 